GURRENT DEBATES

\title{
British Film Policy in an Age of Austerity
}

\author{
Jack Newsinger
}

\begin{abstract}
The rise of The King's Speech from a British independent film to a worldwide commercial and critical phenomenon is a huge testament to the creators, the cast and everyone involved. It's a magnificent final chapter for the UK Film Council. (Tanya Seghatchian, in UKFC 2011)

We are committed to supporting the film industry [...] There is a great tip and key to filmmakers, which is that we must make films that people want to watch, and films that will have a benefit beyond themselves - that also encourage people to come and visit our country. (David Cameron 2010)
\end{abstract}

\section{Introduction}

Speaking to journalists after The King's Speech (2010) won four Oscars in 2011's ceremony, lead actor Colin Firth described the decision to axe the UK Film Council as 'short-sighted' (quoted in Smith 2011). Indeed, The King's Speech makes a suitable memorial to both the strengths and weaknesses of British cinema under New Labour for several reasons.

First would be the film's transatlantic success (alongside numerous awards, $£ 156 \mathrm{~m}$ by February 2011), testament to the way that British talent can punch above its weight internationally. Second might be an acknowledgement that the film follows an entirely conventional strategy of selling British history abroad, in this case the Royal family and in particular the figure of the (literally) stuttering posh boy as symbol of national resolve during Britain's 'finest hour'. Finally we might note that in order to spin this piece of royalist/tourist propaganda together, King George VI's enthusiastic support for appeasement has had to be expunged. As Christopher Hitchens put

Journal of British Cinema and Television 9.1 (2012): 133-144

DOI: 10.3366/jbctv.2012.0065

(C) Edinburgh University Press

www.eupjournals.com/jbctv 


\section{Jack Newsinger}

it: 'Almost the entire moral capital of this rather odd little German dynasty is invested in the post-fabricated myth of its participation in "Britain's finest hour". In fact, had it been up to them, the finest hour would never have taken place' (2011). One wonders if Hitchens' version of Royal history would have played so well at the Oscars?

With the Film Council now gone, it is important not to look back over the last ten years with rose-tinted spectacles, tempting as it might be to view its history as British film policy's finest hour. Therefore this contribution will first offer a critical review of film policy under New Labour before outlining the changes made by the Conservative-Liberal Democrat coalition government so far. The key questions are: to what extent do these changes represent a change of policy? And what might their consequences be?

\section{British film policy under New Labour}

A report prepared for the House of Lords Select Committee on Communications in 2010 gives a useful summary of the state of the British film industry at roughly the end of the New Labour period. It notes that in 2008 the UK was the eleventh largest producer of films in the world by number of films and fifth largest, after the United States, Japan, France and Germany, by production expenditure. In 2006 and 2007, over two-thirds of production spend in the UK was inward investment, almost exclusively from the United States. In 2008 there were 202 active film production companies in the UK. Of these, two produced four feature films each, five produced three each, ten produced two each and the remaining 185 produced just one feature film each. The British production sector, the report notes, 'contains a few large companies making films with substantial budgets and a long tail of small companies producing mainly low-budget films' (House of Lords Select Committee on Communications 2010: 20). At the top end of this scale, international commercial viability continued to be dependent upon some form of integration with a Hollywood Studio (for example, Aardman Animations have a first-look deal with Sony Pictures Entertainment and Working Title is a subsidiary of Universal Studios).

Similarly, distribution continues to be dominated by UK-based subsidiaries of American studios. In 2008, six American-owned companies between them had 78 per cent of the market, and the top ten distributors had 95 per cent. The largest UK-owned distributor is Entertainment, which in 2008 had only eight per cent of the market. This is in contrast to the size of the domestic market for 


\section{British Film Policy in an Age of Austerity}

filmed entertainment (cinema release, DVD sales and rentals, video on demand and so on) which in 2008 was worth more than £3.5bn. This placed the UK third largest in the world after the US and Japan (House of Lords Select Committee on Communications 2010: 18-24).

To summarise, at the end of the New Labour period the domestic film industry in the UK is production led and almost completely dependent upon Hollywood investment. New Labour's film policy has aimed primarily at creating a legislative framework and infrastructure to attract this investment and in this they had notable success. Inward investment, while fluctuating enormously year-on-year, has risen steadily from $£ 182.7 \mathrm{~m}$ in 1994 to $£ 356.8 \mathrm{~m}$ in 2008 and $£ 752.7 \mathrm{~m}$ in 2009 (UKFC 2010: 134).

There are three major determinants of inward capital investment in production: the tax relief system, the existence of labour and facilities, and the currency exchange rate. Given that the third is outside the influence of film policy, what follows will discuss the first two.

Tax relief is an interesting form of subsidy. Since the 1990s it has been widely adopted by countries competing for Hollywood investment internationally and also within the US by state legislatures keen to do the same. In the UK it was first introduced by the Conservative government in 1992, providing incentives for films with budgets over $£ 15 \mathrm{~m}$. After New Labour's election victory, this was complemented by the Finance Act 1997 which permitted a 100 per cent tax write-off in the first year for films with budgets of less than $£ 15 \mathrm{~m}$. This is widely perceived to have been responsible for the steady growth of UK film production to a peak of 180 films in 2002 (second only in number to 1936) but also subject to widespread misuse. As a result, it was closed in 2004 and replaced in 2006 by a new film tax credit system (for a full discussion of the history of tax relief subsidy see Magor and Schlesinger 2009).

The new film tax credit, as noted in the House of Lords report, has been widely praised by industry figures - Michael Kuhn of Qwerty Films, for example, is quoted as describing it as 'fantastic' and designed 'very cleverly, very effectively' (House of Lords Select Committee on Communications 2010: 27). Its key features are that subsidy is provided directly to the film production company-not to those whose only involvement is providing finance - and it is available only to companies making 'culturally British' films, made to be shown in cinemas and where at least 25 per cent of qualifying expenditure will take place within the UK.

Whether a film can be considered 'culturally British' or not is determined by a cultural test, introduced in 2007 as a way to try to 


\section{Jack Newsinger}

ensure a cultural return on investment made through the tax credit system. In order to obtain support, a production is scored against a predetermined set of 'cultural' criteria and awarded points, needing to obtain sixteen points out of a possible 31. Categories include content (whether the story is set in the UK, whether the characters are British, whether it is based upon British source material and so on), cultural contribution (does it reflect diverse British culture, heritage or creativity?), location (what proportion of the production will take place in the UK?) and cultural practitioners (are the cast, crew and producers British or from the European Economic Area?).

Magor and Schlesinger (2009) describe how the cultural test developed through a tension between the wider creative industries' policy of setting up the UK as a production 'hub' in order to attract inward investment and a secondary concern at the European level for cultural protectionism. This explains why in the original cultural test only a minority of points (up to four) were to be allocated for the cultural content of films while nearly four times more (up to fifteen) would have been available for the location of production and postproduction facilities (the 'hub') and nearly the same again for the nationality of personnel (up to thirteen points). This version of the cultural test was, however, rejected by the European Commission and the final point allocation was weighted much more heavily towards content, which went from four to sixteen points. Location was reduced down from fifteen to three and only eight points made available for nationality; the 'cultural contribution' category was also added. The final cultural test is the curious result, therefore, of a transnational body (the EU) defending British cultural nationalism against both Hollywood and the wishes of the UK government.

Accurate estimates of the value of tax relief subsidy are difficult to make. However, according to the House of Lords, the tax credit system was worth $£ 105 \mathrm{~m}$, or 40 per cent of public funding for film, in $2007 / 8$. Tax relief is, then, by far the largest single subsidy to film made by the UK government and is designed solely to provide incentives to Hollywood studios to invest in 'culturally British' production as opposed to, say, Australian production or production in Kentucky.

As Magor and Schlesinger (2009) note, tax relief is distinguished by the lack of intervention required once the legislative framework has been put in place. It is, then, a particularly market-orientated form of subsidy that places government support outside of democratic control, subject to the political economy of the international market. There is evidence that it can create a 'race to the bottom' as competition between countries, regions and states intensifies (House of Lords Select 


\section{British Film Policy in an Age of Austerity}

Committee on Communications 2010; National Centre for Policy Analysis 2011). The primary beneficiaries are the Hollywood studios which are able to use their industrial power and capital mobility to push down costs such as tax and labour at a global level.

Nevertheless, the cultural test represents a genuine attempt to carve out a recognisably British product - a national cinema-from Hollywood's transnational investment capital and production practices. It reflects, therefore, an official conception of the particular cultural value of the film industry as opposed to, say, tax credits for foreign investment in British car manufacturing. For Andrew Higson (2011) it is something of a landmark: the first time that an official film policy scheme had adopted any form of cultural criteria. For him, 'The new scheme $[\ldots]$ endeavored to strike a balance between inward investment and cultural Britishness - with the two brought together in the form of investment in a UK industrial infrastructure and labour force' (56-7). He calls the cultural test a 'curious mixture of the national and the transnational' (59) and argues that it is best understood as a piece of cultural policy as opposed to economic policy.

The second major determinant of inward investment in the film industry is the availability of cheap, skilled labour. New Labour policies combined overall growth with the consolidation of existing trends towards independent production in the film and broadcast sectors. The centrality of small and medium sized enterprises (SMEs) and the independent media entrepreneur to the creative industries discourse reflected a conscious structural transformation towards an increasingly flexible, casualised labour force. For example, in 1996 there were 1,745 registered companies working in film and video production which had increased to 7,970 in 2008, more than a fourfold increase. The proportion of companies with a turnover of between $£ 1,000$ and $£ 99,000$ was 57 per cent, which is significantly higher than the average for other industries. While in 1996, the film industry had relatively fewer small companies than the UK as a whole, by 2008 the opposite was the case. Almost half (46 per cent in 2008) of those working in the production sector are self-employed, compared to 13 per cent for the British workforce as a whole (House of Lords Select Committee on Communications 2010: 23).

The availability of skilled, flexible labour is perceived to be one of the key competitive advantages that the UK offers in the international market and central to its success in attracting Hollywood investment. However, training the right amount of people with the right skills is a problem for the British film industry. Essentially, a fragmented industry based upon transient capital investment, 


\section{Jack Newsinger}

short-term contracts and flexible labour is both unable and unwilling to devote significant resources to long-term workforce development. This has been one of the key roles adopted by the state since the 1990s, which is justified through the disproportionate degree of prestige and economic importance attached to the creative industries within public policy (Garnham 2005).

In the New Labour period, the UK Film Council and the Regional Screen Agencies (RSAs) were the main institutional mechanisms by which public money was pumped into workforce and infrastructure development, which included initiatives such as First Light, the British Film Commission and the New Cinema Fund. The Regional Screen Agencies in particular make an interesting case study of the convergence of economic, social and cultural policy under New Labour. As a 2006 DEMOS report put it, RSAs were intended to 'develop a sustainable UK film industry by developing the pool of creative skills and talent; developing entrepreneurial acumen and business clusters; and developing an industrial infrastructure' (Holden 2006: 37). He continued:

The RSAs do not see themselves as funders of screen culture, but prefer to see themselves as investors in it. They do this by developing the competitiveness of businesses, assisting to build critical mass, addressing skills shortages, developing talent and innovation and offering sectorspecific advice and expertise. (Ibid.: 28)

This resulted in a massive increase in digital short-film schemes and low-budget feature film production, often by first-time directors, including the development of genuinely innovative production models (Sheffield-based WARP Films, for example, or the iFeatures initiative in Bristol). However, while this funding created inroads to the industry for previously marginalised social groups and allowed many people to make films who would not otherwise have been able to do so, for every Shane Meadows that has come through this system there are many more people working long hours on low pay in short-term contracts with very little creative control over what they make. What is more, despite the rhetorical emphasis on diversity and social inclusion that anyone who has read Film Council policy documents will be familiar with, the available data shows that employment practices in the film industry remain inherently discriminatory and nepotistic (see, for example, Skillset/UK Film Council 2009; Skillset 2010). Expansion combined with casualisation represents, in my view, a major and largely unrecognised contradiction in New Labour's film policy and 


\section{British Film Policy in an Age of Austerity}

in the creative industries policy discourse more generally (for a fuller discussion of this point see Newsinger 2012).

New Labour's film policy has clearly had a degree of success on its own terms. As Higson notes, at the end of the New Labour period British film production was 'far more stable and substantial than many might have imagined in the mid-1980s, at a time when government support for the film industry seemed to have disappeared altogether, when cinema-going as a cultural practice and profitable enterprise seemed to be dying out, and when the global media entertainment business seemed to leave little room for smallscale national productions' (2011: 11-12). However, the strategy is vulnerable to both fluctuations in the pound-dollar exchange rate and international competition to provide facilities, labour and subsidy to Hollywood studios. Furthermore, the sense of the British film industry as a cheap outsourced Hollywood assembly plant may not be everyone's aspiration for British cinema.

\section{Coalition film policy}

How has UK film policy changed since the election of the Conservative-Liberal Democrat coalition government in May 2010? The first big announcement in July was the surprise closure of the UK Film Council. As the organisation's chief executive, John Woodward, put it:

On Wednesday, we were a valued DCMS agency; by Friday, we were on a list that enabled it to help meet the Treasury's targets for cutting UK public bodies, as part of the effort to reduce the country's £156bn budget deficit over the next four years. It's blitzkrieg, but without any forward planning. (2010)

The Department for Culture, Media and Sport has since been criticised by the National Audit Office for its failure to conduct a financial analysis of the costs of the decision, particularly in terms of lease cancellation, redundancy and pension costs. As part of the so called 'bonfire of the quangos', the winding-down costs of the UKFC alone amount to $£ 11.3 \mathrm{~m}$, which is considerably more than the $£ 3 m$ the organisation spent on administration annually, one of the principal reasons for its demise (Sweney 2011). In what proved to be something of a political own-goal, the announcement came across as a rushed slash-and-burn exercise as opposed to the strident defence of taxpayers against overpaid, mini-Hollywood executives that it was presumably intended to be. 


\section{Jack Newsinger}

The initial response from industry figures was almost uniformly negative. For example, a letter to the Guardian from Directors UK (a guild for film and television directors) argued that 'Over 10 years [the UKFC] has made a huge contribution to elevating the status of British film and has financed or sponsored a large number of highquality, successful productions' (2010). In a letter to the Telegraph, 50 leading film and television actors-including Bill Nighy, Timothy Spall, Emily Blunt and James McAvoy - criticised the decision, arguing that 'Everyone, including those in the film industry, knows that times are tough. But the UKFC doesn't waste money, it makes it. Thanks to its efforts, our film industry - worth $£ 4.5$ billion a year - has rarely been stronger' (quoted in Porter 2010). Concern was also expressed publicly from across the Atlantic with Clint Eastwood and Steven Molen from DreamWorks worrying about the continuation of location services and support for international production in the UK (BBC 2010; Prince 2010).

On the other hand, film-maker Alex Cox argued that the closure of the UKFC was

very good news for anyone involved in independent film. The Film Council became a means by which lottery money was transferred to the Hollywood studios. It pursued this phoney idea that James Bond and Harry Potter were British films. But, of course, those films were all American-and their profits were repatriated to the studios in Los Angeles. (Quoted in Bennett 2010)

Similarly, from Colin McArthur: 'All sympathy to those about to lose their jobs, but the UK Film Council has been hoist by its own petard $[\ldots]$ it shovelled heaps of sterling into the already bulging pockets of the American majors' (2010). There was the sense, then, that the chickens had come home to roost for the UKFC.

Putting Schadenfreude to one side, the real question is the extent to which the decision represented a qualitative change of policy. It was not until the autumn that Ed Vaizey, Minister for Creative Industries, announced the Coalition's 'exciting new vision for the British film industry' (2010). This features the transference of the UKFC's functions to the British Film Institute and the closure of the majority of the Regional Screen Agencies, to be replaced by three regional hubs with reduced budgets, renamed Creative England. The work of the British Film Commission will be assumed by Film London which has been exempt from the Creative England structure but with a 20 per cent cut in its grant-in-aid. In common with cuts across DCMS's funding portfolio, the BFI itself will have its funding reduced by 


\section{British Film Policy in an Age of Austerity}

15 per cent over four years, along with a reduction in the grant-in-aid funding for film from the Treasury from $£ 23.9 \mathrm{~m}$ in $2010 / 11$ to around $£ 18.6 \mathrm{~m}$ (Goodridge 2010). On the other hand, the tax credit system will continue in its existing form and Lottery funding for production will be increased from $£ 27 \mathrm{~m}$ per year to $£ 43 \mathrm{~m}$ by 2014 (Vaizey 2010). At the time of writing the government has announced a new film policy review by an appointed panel chaired by Chris Smith which is due to report before the end of 2011. Perhaps the 'exciting' and 'new' aspects of the Coalition's vision will become clearer then?

\section{Conclusion}

The above sketch raises a number of issues for the debate on film policy. Firstly, anguish or delight at the demise of the UK Film Council is misplaced, as much of what happened to British cinema during its tenure was outside of its control. The organisation is primarily judged on what kind of films it invests in which, while contentious, is a relatively small overall component of film policy and pretty subjective. Important decisions that affect the structure and size of the UK film industry are made by the Treasury, the government and the international market. Magor and Schlesinger note, for example, that the extension of the film tax credit system and its incorporation into British film policy can hardly be attributed to the Film Council; indeed, they were first informed of the Chancellor's decision to extend the credit in 2001 by Jack Valenti, chairman of the Motion Picture Association of America (2009: 309). Equally, the decision to axe the UK Film Council seems to have been driven less by strategic concerns and more by short-term political expediency. There is little evidence of an overall change of policy outside of more general reductions in the size of government expenditure in response to the global recession. It remains to be seen exactly how transferring the responsibilities of the UK Film Council to the British Film Institute will affect the kind of films that get funded, but my guess is not very much.

Secondly, it is common in the mainstream media and in much academic writing to discuss the UK film industry as if it is a single entity with a unified set of interests, the main reason for argument being about how best to serve those interests. But this is not the case: the British film industry is structurally and geographically diverse with different sections having separate, sometimes compatible, sometimes competing, interests. While no one would dispute the value to British film and television workers of inward investment, much of the UK's international competitiveness has been based upon a long-term 


\section{Jack Newsinger}

pattern of lowering the quality of working conditions for labour. The primary beneficiaries are the Hollywood studios and, to a lesser extent, their British-based producers. For a long time the ears of government have listened exclusively to these business interests. As a result, New Labour responded enthusiastically to the new international division of cultural labour, subordinating other concerns in film policy to its logic. Cultural and social aims were fine, but only in so far as they could be justified in terms of training, infrastructure development, tourism and so on, and only in so far as they did not interfere with commercial interests. To take one relatively random example, the UKFC's Diversity Action Group argues that 'filmmaking is about teamwork and diverse teams are more likely to be innovative and creative than those that are not' (2003: 2). The obvious point is that a link between 'diversity' and 'innovation' is far from self-evident (the film industry has been 'innovating' without being 'diverse' so far). It is also revealing to point out that this statement was written by Tim Bevan, who, as well as being Chair of the UKFC's Leadership on Diversity in Film Group, is CoChair of Working Title Films, undoubtedly a commercially successful film production company, but not one noted for its contribution to diversity in British cinema. As in New Labour cultural policy more generally, the UKFC was unable to make a case for 'diversity' that was not based on commercial criteria, as opposed to a moral or political argument.

This critique notwithstanding, it is the social and cultural aspects of film policy that we can expect to suffer under the current regime. Warner Bros' recent acquisition and planned development of Leavesden Studios, home of the Harry Potter franchise, appears to give the Hollywood seal of approval to the Coalition's film policy (see Sabbagh and Sweney 2010). Contrary to initial fears, the support for Hollywood investment that was central to New Labour's film strategy will be maintained. The tax credit system administered through the cultural test is widely perceived to be an effective way to leverage Hollywood dollars towards British companies while also differentiating product enough for a distinctively British cinema to emerge.

Conversely, the more directly social and cultural aspects of film policy have taken a hammering with large cuts to organisations that fund film activity at a grassroots level such as the BFI and the Regional Screen Agencies. So while operators like Clint Eastwood, DreamWorks and Directors UK might be breathing a sigh of relief for the moment, this spells trouble for independent film-makers in Nottingham or Newcastle. In short, these cuts will disproportionally affect the poorer, 


\section{British Film Policy in an Age of Austerity}

more independent and vulnerable parts of the film sector, particularly those outside the metropolitan elite.

In the 1980s commercial subsidies were slashed leading to the almost complete collapse of commercial feature film production in the UK. At the same time, cultural film subsidy was maintained at a certain level, mostly through the British Film Institute and Channel 4 (Dickinson and Harvey 2005). This time the Coalition is pursuing the opposite strategy: the maintenance of subsidy to the commercial film sector at the expense of state support for the remaining remnants of a socially and culturally progressive film policy in the UK.

\section{References}

BBC (2010), 'Clint Eastwood writes plea to save UK Film Council ', at: http://www. bbc.co.uk/news/entertainment-arts-10911948, accessed 18 June.

Bennett, R. (2010), 'Axing the Film Council: a move that impoverishes us all', at: http:// www.guardian.co.uk/film/2010/jul/26/uk-film-council-abolished-reaction, accessed 18 June 2011.

Cameron, D. (2010), 'House of Commons Debate', Hansard, Vol. 518, Part 73, col. 884-5, at: http://www.publications.parliament.uk/pa/cm201011/cmhansrd/ cm101117debtext/101117-0001.htm), accessed 10 June 2011.

Dickinson, M. and Harvey, S. (2005), 'Film policy in the United Kingdom: New Labour at the movies', Political Quarterly, 76: 3, pp. 420-9.

Directors UK (2010), 'Letters: Build on the success of the UK Film Council', at: http:// www.guardian.co.uk/business/2010/jul/28/build-on-uk-film-council, accessed 13 June 2011.

Garnham, N. (2005), 'From cultural to creative industries: an analysis of the implications of the "creative industries" approach to arts and media policy making in the United Kingdom', International Journal of Cultural Policy, 11: 1, pp. 15-29.

Goodridge, M. (2010), 'Non-Lottery, non-BFI film funding to be chopped in half as part of UK's budget cuts', at: http://www.screendaily.com/news/uk-ireland/non-lotterynon-bfi-film-funding-to-be-chopped-in-half-as-part-of-uks-budget-cuts/5019679. article, accessed 18 June 2011.

Higson, A. (2011), Film England: Culturally English Filmmaking since the 1990s, London: I. B. Tauris.

Hitchens, C. (2011), 'Churchill didn't say that: The King's Speech is riddled with gross falsifications of history', at: http://wwvv.slate.com/id/2282194/ accessed 13 June, 2011.

Holden, J. (2006), The Big Picture: The Regional Screen Agencies Building Community, Identity and Enterprise, London: Demos.

House of Lords Select Committee on Communications (2010), The British Film and Television Industries - Decline Or Opportunity? Vol.1: The Report, London: HMSO.

McArthur, C. (2010), 'Letters: Grubby deals behind the axing of the Film Council', at: http://www.guardian.co.uk/business/2010/jul/29/axing-of-the-film-council, accessed 13 June 2011.

Magor, M. and Schlesinger, P. (2009), "For this relief much thanks." Taxation, film policy and the UK government', Screen, 50: 1, pp. 299-317.

National Centre for Policy Analysis (2011), 'Economic effects of film tax credits overstated', at: http://www. ncpa.org/sub/dpd/index.php?Article_ID+20503, accessed 15 June 2011. 


\section{Jack Newsinger}

Newsinger, J. (2012), 'The politics of regional audio-visual sectors in England: or, how we learnt to stop worrying and get "creative" , International Journal of Cultural Policy, 18: 1, pp. 111-25

Porter, A. (2010), 'Leading actors and actresses condemn plan to scrap UK Film Council', at: http://www.telegraph.co.uk/culture/film/film-news/7927407/Leadingactors-and-actresses-condemn-plan-to-scrap-UK-Film-Council.html, accessed 14 June 2011.

Prince, R. (2010), 'Steven Spielberg joins campaign against abolition of UK Film Council', at: http://www.telegraph.co.uk/news/politics/7941502/Steven-Spielbergjoins-campaign-against-abolition-of-UK-Film-Council.html, accessed 18 June 2011.

Sabbagh, D. and Sweney, M. (2010), 'Warner Bros buys Harry Potter studios in £100m boost for UK films', at: http://www.guardian.co.uk/media/2010/nov/09/warner-brosleavesden-studios, accessed 18 June 2011.

Skillset (2010), Women in the Creative Media Industries, London: Skillset.

Skillset/UK Film Council (2009), Skillset/UK Film Council Feature Film Production Workforce Survey 2008, London: Skillset/UK Film Council.

Smith, N. (2011), 'Oscars 2011: Film Council basks in King's Speech glory', at: http://www.bbc.co.uk/news/entertainment-arts-12593892, accessed 15 June 2011.

Sweney, M. (2011), 'Jeremy Hunt's UK Film Council plan criticised by audit office', at: http://www.guardian.co.uk/media/2011/mar/10/jeremy-hunt-uk-film-council, accessed 10 March 2011.

UKFC (2003), Success Through Diversity and Inclusion, London: UK Film Council.

UKFC (2010), Statistical Yearbook 2010, London: UK Film Council.

UKFC (2011), 'Oscars for a King: the UK Film Council funded film scoops four Oscars', at: http://www.ukfilmcouncil.org.uk/kingoscars, accessed 13 June 2011.

Vaizey, E. (2010), 'The future of the UK film industry', at: http://www.culture. gov.uk/news/ministcrs_speeches/7602.aspx, accessed 16 May 2011.

Woodward, J. (2010), 'Why scrapping the Film Council is a catastrophe', at: http://www. guardian.co.uk/film/2010/jul/26/john-woodward-film-council, accessed 13 June 2011.

Jack Newsinger is lecturer in Media and Communication at the University of Leicester. His research interests include British film, cultural policy and the creative industries. 